\title{
IN MEMORIAM PETRE T. FRANGOPOL
}

\section{(1933-2020)}

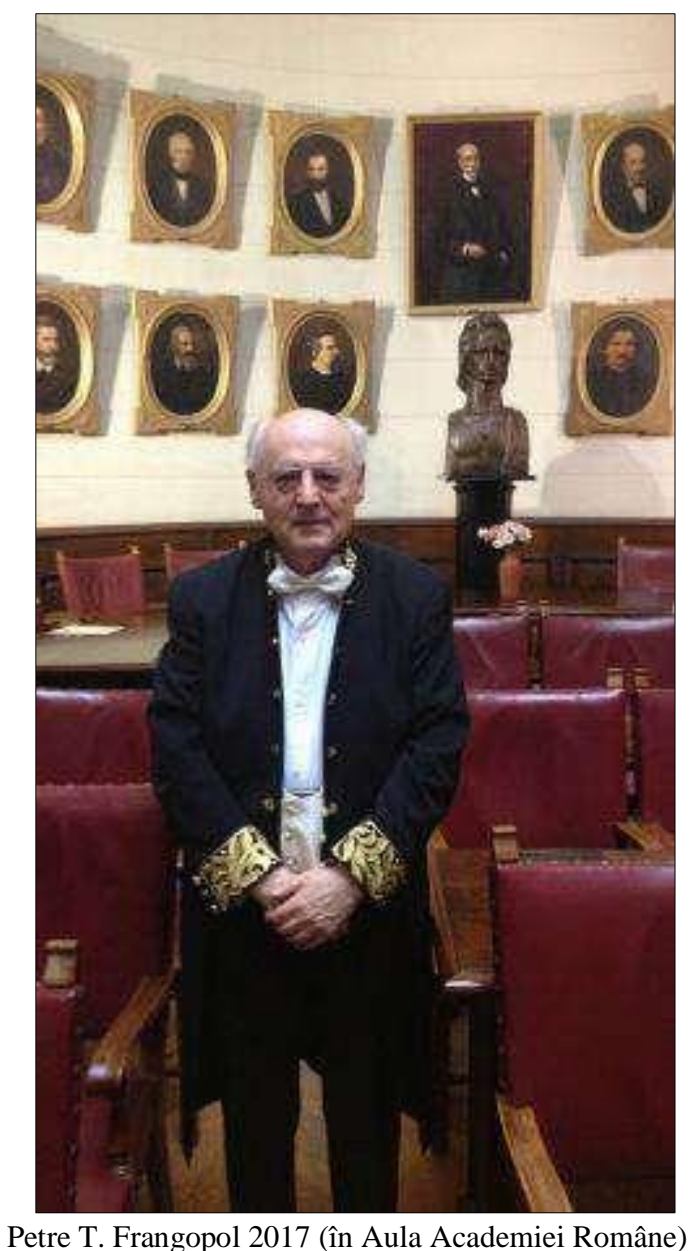

S-a împlinit un an când comunitatea ştiinţifică şi academică din România şi din străinătate a primit cu durere o veste foarte tristă: trecerea în veşnicie a Profesorului universitar Dr. Ing. Petre T. FRANGOPOL, membru de onoare al Academiei Române (A.R.), o personalitate unică în istoria chimiei şi culturii române, un om de mare caracter.

Petre T. Frangopol era foarte mândru de saga familiei sale, relatată cu mai multe ocazii, inclusiv în Adunarea Generală a A.R. din 8 octombrie (oct.) 2018 dedicată celei de a 85-a aniversări a sale. Am avut onoarea de a fi fost invited speaker la eveniment (prezentat și în revista Academica, Vol. XXVIII, 34-63, 2018). Străbunicii săi au venit din Bulgaria, de la Mesemvria (Nesebăr de azi), localitate la sud de Varna, ca urmare a unei purificări etnice făcute de bulgari, satul fiind $100 \%$ populat de greci. În revista Tomisul Cultural (editată de comunitatea elenă ELPIS Constanţa) P. T. Frangopol a publicat în 2016 o serie de articole foarte interesante în care s-a ocupat de istoria numelui și a familiei Frangopol din Constanţa. Redau mai jos informații prelucrate din aceste articole. În cele opt expediții (cruciade) întreprinse cu trupe armate între secolele XI și XII de Europa creștină pentru recucerirea locurilor sfinte din Ierusalim, căzute în mâna turcilor, armatele stabileau în drumul lor garnizoane fixe, permanente, mai exact construiau cetăți mari, fortărețe înconjurate de locuințe. Acestea erau locuri de popas și de alimentare a miilor de cruciați. Una dintre aceste garnizoane era în centrul Peloponezului, la Mistra, aproape de Sparta. Din relațiile cruciaților cu localnicele s-au născut „puii francilor” sau franco poulis (în limba greacă Pouli însemnând pui). De aici a derivat numele de Frangopoulos, terminația fiind caracteristică numelor de familie a celor originari din această parte a Greciei. Ultimul împărat al Bizanţului din dinastia Paleologu și-a alcătuit curtea imperială și din demnitari din zona Mistra, deci 
purtând numele de Frangopoulos. După cucerirea Constantinopolului de către turci (1453) populația greacă a orașului s-a împrăștiat în mai multe direcții, o mare parte găsindu-și refugiul în zonele de coastă ale Mării Negre (inclusiv Bulgaria de azi), unde existau așezări grecești întemeiate î. de Chr. de valuri de coloniști greci. Una din aceste localități din Bulgaria care a primit refugiați din Constantinopol era și Mesemvria (Nesebăr de azi, care în 1983 a fost inclus în lista monumentelor istorice ale tezaurului UNESCO, deci aparține moștenirii culturale mondiale). Bulgarii, de origine turco-mongolă, s-au stabilit în ținutul de la Sud de Dunăre între secolele VI și IX d. Chr., adoptând limba și moravurile Slavilor, devenind un puternic stat balcanic sub diferiți țari, care a fost anexat de Bizanț și apoi cucerit de invazia turcă și înglobat în imperiul otoman. Emanciparea Bulgariei a început în secolul XIX cu ceea ce numim astăzi purificare etnică. Grecii din Mesemvria au început a fi obligați ,,pașnic” să plece, după aprecierea prof. Frangopol, în jurul anilor 1850. Li s-a spus că dacă nu părăsesc Mesemvria, în timp, ei, bulgarii, vor da foc la case și la tot avutul lor. Astfel a început bejenia familiei Frangopol, care și-a vândut averea şi a venit, cu turmele de oi și alte animale către Nord, în Dobrogea de azi, stabilindu-se în 1860 în Kiustengé, denumirea turcească a satului din care s-a dezvoltat Constanţa de astăzi. Spre deosebire de satele din Dobrogea de pe malul drept al Dunării care erau întemeiate şi populate de români, mocani veniţi cu oile din părţile Ardealului, Dobrogea costieră de astăzi, era un ţinut al nimănui, pârjolit de războaiele ruso-turce care încep din a doua jumătate a sec. XVIII şi durează până spre sfârşitul sec XIX. Războiul Crimeei (1853-1856) transformase Dobrogea într-un cimitir şi un pustiu. Kiustengéul era un sat sărac, ce avea în 1840 patruzeci de colibe acoperite cu stuf, conform mărturiilor din cărţi (apărute la Paris în 1859 şi la Berlin în 1854), scrise de medici ofiţeri francezi şi nemţi ai trupelor turceşti. Interesantă este caracterizarea aspectului locuitorilor Dobrogei şi ai Kiustengéului făcută de un medic francez. El constată că românii din satele de pe malul drept al Dunării, au figuri aproape celtice, dar spre Kiustengé populaţia este de tip italian, latin şi au o inteligenţă care-i caracterizează într-un grad aşa de înalt... trebuie să existe în ei o forţă de resort foarte remarcabilă, ca să fi putut rezista vieţii de frică şi de mizerie, cu care se confruntă de atâta timp.

Grecii din Mesemvria şi-au croit o nouă viaţă în Kiustengé, plecând de la zero. Petre T. Frangopol era originar dintr-o familie stabilită la Kiustengé în 1860. Erau cinci fraţi, cu vîrste între 17 şi 30 de ani, toţi născuţi la Mesemvria, care s-au hotărât să îşi facă un rost în viaţă în Dobrogea. Au vândut averea familiei şi s-au stabilit la Kiustengé, care începuse să înflorească economic după războiul Crimeei. Posedau o reţetă originală de preparare a caşcavalului (obţinută de la mănăstirile greceşti), şi, pornind de aici, au dezvoltat un negoţ de coloniale (aşa se numeau produsele din import: mirodenii, citrice etc) şi de produse lactate, printre care şi caşcavalul de Dobrogea, cu aromă şi gust specific, cunoscut ulterior în toată România şi peste hotare. Dintre fraţii Frangopol s-a remarcat Ralli (18431931). P.T. Frangopol a descoperit în ziarul constănțean Marea Noastră (din 1 martie 1931) un articol în care scria: „Dintre bătrânii autohtoni dobrogeni, trei, patru, câți mai rămăseseră, s-a dus încă unul, Ralli Frangopol. Devotați muncii și familiei, respectuoși față de legile și tradițiile țării, oamenii aceştia fără să fi făcut vreodată paradă de sentimente ori să se înfrupte carecumva din bugetul public, s-au comportat ca cei mai merituoși și veritabili patrioți. Da, Ralli Frangopol a fost un adevărat patriot în sensul clasic al cuvântului."

Bunicul lui Petre Frangopol, pe care-l chema Petre, era frate cu Ralli. Bunicul Petre nu avea calităţi de negustor sau de agricultor şi nu a făcut avere ca fraţii săi. A fost translator, ştia limbile moderne ale momentului (turca, tătara, bulgara, rusa, greaca, româna) şi era util autorităţilor şi trupelor de ocupaţie ruseşti. Şi-a vândut partea sa (şi a fiilor lui) de 10 hectare primite ca împroprietărire de la Guvernul României din domeniile statului, cum s-au dat fiecărui nou cetăţean român care se afla în Dobrogea la alipirea acesteia (1877) la România.

P.T. Frangopol afirmă: „În mod neîndoios, această ascendenţă de oameni săraci, dar curajoşi, care au reuşit să-şi croiască o nouă viaţă pe pământul dobrogean după ce au fost izgoniţi din vatra lor, această saga a familiei auzită în copilărie mi-a influenţat caracterul şi a încurajat voinţa mea de afirmare în profesia aleasă." În articolele din Tomisul Cultural P.T. Frangopol evocă și primii ani de viaţă. S-a născut la 26 mai 1933 la Constanţa, ambii părinţi fiind greci: Tatăl Theodor (născut în Constanţa în 
1887), iar Mama Ecaterina (născută în 1904 la Varna). A văzut lumina zilei într-o casă de pe strada Marc Aureliu nr 25, ale cărei ferestre aveau în faţă strada Mării, micuţă, care se termina la mai puţin de o sută de metri pe un versant abrupt care străjuia marea şi pe care era construit Palatul Şuţu, vilă construită în stil maur la sfârşitul secolului XIX, de primul Guvernator al Băncii Naţionale a României, descendent al ultimilor domnitori fanarioţi ai MoldoveI şi Ţării Româneşti. Farmecul mării 1-a fascinat de mic copil, plaja şi marea constituind „o a doua natură” a existenţei sale.

Tatăl său, după absolvirea a cinci clase primare, a început să lucreze de la 12 ani la căşeriile de la Hârşova, până a fost luat în armată. A fost concentrat mai mulţi ani neîntrerupţi, apoi a fost pe front în primul război mondial unde statul în tranşeele pline de apă 1-au îmbolnăvit de un „,runt şi dureros reumatism cronic articular”. A fost magazioner la cea mai mare firmă de import-export mărfuri coloniale din Constanţa, unde lucra de dimineaţa până seara, când venea frânt de oboseală acasă. Ținea cu religiozitate într-un sertar încuiat (abia când a murit a putut fiul său să vadă ce ascundea el acolo) actul de cetăţean şi de supus român semnat de Regele Carol I. Era un avid cititor al presei şi revistelor ilustrate, care i-au deschis copilului său interesul pentru a învăţa să scrie înainte de a intra în clasele primare, apoi să citească presa (cât putea să priceapă!), obicei care nu 1-a părăsit până la finele vieții. Tatăl îi explica ce nu pricepea din cele citite şi îi sublinia că citeşte presa fiindcă trebuie să ştie ce se petrece în oraş, în ţară, peste hotare. Era foarte mulţumit de apetitul precoce de avid cititor al fiului şi-1 stimula, abonându-1 la revista Universul Copiilor sau la colecţiile de broşuri periodice de poveşti şi istorioare pentru copiii de vârsta sa.

Mama 1-a învăţat pe fiul său cum să se expună zilnic la soare, gradat, un număr crescut de minute, până ce nu mai exista limită de timp a expunerii la soare, datorită mantiei de bronz care-i acoperea trupul. După vârsta de patru ani căpătase încrederea Mamei care îl lăsa zilnic la plajă, ore în şir, în compania băieţilor mai mari de pe stradă, cu promisiunea că nu se aventurează mai departe în mare, singur, peste o adâncime ce nu trebuia să treacă de genunchi. Încet, încet, a înţeles necunoscutele mării, vietăţile ei, tainele ei şi cu ajutorul şi grija celor mai mari băieţi din cartier, a învăţat să înoate şi să nu se mai sperie de gustul sărat al apei şi al adâncimii unde se încumeta să înainteze, treptat, curajos. Jocurile din apa mării constituiau deliciul orelor petrecute pe plajă sub un soare dogoritor pe care nu îl mai simţea. A învăţat să pescuiască, cu undiţe dintre cele mai rudimentare. $\mathrm{Cu}$ anii, înotul devenise o a doua natură a existenţei cotidiene, care le dădea copiilor încredere şi mai ales curaj să înveţe să fie prudenţi, dar să şi înfrunte valurile mării fără teama de apă, şi să nu se aventureze prea departe, de teama cârceilor şi a situaţiilor neprevăzute care puteau apare. Învăţa instinctiv cu grupul de copii din mahalua străzii să creeze o solidaritate care i-a folosit mult în viaţă. Încrederea părinţilor era foarte mare şi nu a existat nici un accident sau înnec. Precauţia a fost una din lecţiile vieţii pe care a învăţat-o de mic copil. Cuvântul dat Mamei să respecte nişte reguli cât timp copiii erau singuri pe plajă, devenise o datorie de onoare şi încredere reciprocă. A cunoscut marea îndeaproape, în toate anotimpurile: vara, când era cea mai calmă, uneori strălucitoare ca luciul unei oglinzi cu un colorit albastru care-i mângâia sufletul şi privirea care nu se mai sătura să scruteze orizontul, sau iarna când se dezlănţuia crivăţul şi valurile negre înalte, sălbatice se spărgeau de dig, pe care-1 măturau într-o furie dezlănţuită a naturii. Panorama era unică; mai târziu, revenind la Constanţa în concediu, contemplarea mării îl determina să strige, în sinea sa, bucuria şi fericirea de a o revedea: thalassa, thalassa (marea, marea), precum au exclamat cei zece mii de soldaţi ai lui Xenofon, care după o retragere de 16 luni, au zărit marea.

Petre T. Frangopol a beneficiat de o solidă educaţie, începând cu cea din familie și continuând cu învățământul public de toate gradele. La grădiniţă mergea singur, traversând cu mare atenţie trei artere principale ale oraşului. S-au întipărit în memoria copiilor dragostea cu care educatoarea, Doamna Gheţu, s-a apropiat faţă de fiecare copil. „Avea o căldură şi o blândeţe neobişnuită care ne fermeca pe noi copiii, atenţi să nu o supărăm sau să ieşim din vorba ei."

Părinții 1-au dat la școala românească, spre a privi viitorul și a gândi ca un român. Își amintea de prima zi de şcoală primară, unde a fost condus de Tatăl său: „Drumul trecea pe lângă Şcoala Elenă, vizavi de Biserica Grecească, cu învăţământ integral în limba greacă. Mi-a strâns mânuţa şi mi-a spus apăsat: tu ai nume grecesc, dar să ştii că eşti român ca şi tatăl tău care a luptat pe front pentru această 
ţară, pe care să o iubeşti ca şi mine; nu ai ce căuta la şcoala greacăa."

P.T. Frangopol a urmat școala primară nr 1 din Constanța (1940-1944), unde a avut un învățător excepțional, Gheorghe Enăchescu, pe care 1-a evocat cu recunoştinţă și nostalgie. „Era pentru noi un membru al familiei. Căldura cu care ne înconjura, dojana blândă, rareori mai dură, avea un efect pe care nu 1-ar fi avut dacă ne-ar fi pălmuit pentru năzbâtiile pe care le făceam, uneori în clasă, dar, mai ales, în curtea şcolii...Eram o clasă multietnică, cum s-ar numi azi, o clasă care ilustra perfect diversitatea populaţiei oraşului şi a Dobrogei, dar nouă ni se părea absolut normal să stăm în aceeaşi bancă cu colegi care aveau altă limbă maternă, altă religie, iar domnul Enăchescu ne trata pe toţi la fel... Învăţătorul nostru era un excelent pedagog... Scrisul, cititul, primele operaţii aritmetice erau preocuparea sa principală. În clasa a II-a ne-a ameninţat că făă tabla înmulţirii ştiută ca pe apă rămânem repetenţi. În vreme de iarnă se crăpau şi se spărgeau tăbliţele de ardezie pe care am învăţat să scriem în clasa I. Când plecam de la şcoală şi întâlneam un gheţuş în drum, foloseam ghiozdanul în loc de... sanie. Din fericire, în iarna următoare abandonasem tăbliţa în favoarea creionului şi a caietului special liniat, pentru un scris caligrafic (pe care și 1-a păstrat până la finalul vieții). Aceasta era etapa a doua a emancipării noastre, a treia fiind şi cea mai...dramatică: scrierea cu toc, peniţă şi cerneală. Erau celebre pe atunci peniţele klaps apreciate de noi, dar nu prea uşor de folosit. Când greşeam, ştergeam cu o gumă primitivă, hârtia se subţia, iar la rescriere se găurea. Mama rupea pagina, acompaniată de dureroasele noastre proteste şi disperări, iar caietul se subţia de la o zi la alta...Având o temeinică şi vastă cultură generală, orele învăţătorului erau un fel de dialog cu noi, la nivelul nostru, dar plin de învăţăminte din diverse domenii. Nu era zi în care să nu aflăm câte ceva, fie despre antichitatea greco-romană, fie despre geologie, despre istoria noastră sau a lumii, despre geografie etc. Folosea o metodă care azi s-ar putea numi multi-media. Lecţiile sale erau ilustrate cu planşe colorate, cu hărţi şi alte mijloace care ne făceau să înţelegem lucruri şi chiar idei neobişnuite la vârsta noastră. Ne amintim, de pildă, că în clasa a IV-a a adus o busolă. Am aflat, astfel, de punctele cardinale şi de magnetismul pământului. Descopeream astfel gustul de a citi şi de a afla lucruri noi despre lumea în care ne începeam viaţa. Ne amintim cu multă plăcere şi de cărţile de citire care, de la an la an, ne familiarizau cu numele unor clasici ai literaturii noastre, de la Eminescu şi Creangă, la Coşbuc şi Sadoveanu... amintim maxima latinească citată de învăţătorul nostru ori de câte ori i se oferea ocazia: Dacă tăceai, filozof rămâneai. Şi, cum ocazii avea destule, maxima ni s-a întipărit în minte pentru totdeauna. Respectul faţă de cuvântul rostit sau scris, din copilărie ni l-am însuşit. Avea Dl. Enăchescu oroare de vorbele aruncate în vânt, pretindea din partea noastră, nişte copii, o rigoare, o sobrietate a exprimării care ne-a ferit mai târziu de stilul pompos, umflat, chiar şi atunci când devenise folosit pe scară largă. Echilibrul, calmul, discernământul - erau calităţile sale din care, sperăm, am păstrat şi noi câte ceva...Învăţătorul nostru a fost concentrat în timpul războiului (1941). Noi eram în clasa a II-a şi la reîntoarcere, când a intrat în clasă, toţi elevii neam ridicat în picioare şi-am ţipat de bucuria revederii. A fost o manifestare spontană, de ataşament sincer, din inimă, de neuitat. Ne insufla sentimente patriotice: dimineaţa, la prima oră, cu toată clasa în picioare, învăţătorul Enăchescu, pomenea grav, numele ofiţerilor şi trupei (sergenţi şi soldaţi) toţi de marină, ale căror tablouri cu portretele lor se găseau atârnate de pereţii clasei, iar noi după menţionarea fiecărui nume, rosteam, grav, mort pentru Patrie, după care toată clasa, rostea rugăciunea Tatăl Nostru...elevii de alte confesiuni (catolică, protestantă, iudaică, mahomedană) nu spuneau rugăciunea, dar stăteau în picioare, solidari cu noi. Țara era în război, noi eram seria 1940-1944 şi luptele de pe mare erau la ordinea zilei. Şi nimeni nu putea fi indiferent...Cel ce ţi-a îndrumat primii paşi în viaţă nu poate fi uitat... Acesta a fost învăţătorul Gheorghe Enăchescu care, cu răbdare şi pricepere, cu o reală vocaţie de pedagog, ne-a insuflat, ne-a educat o calitate esenţială: curiozitatea. Şi, poate chiar mai mult decât atât, ne-a învăţat să iubim învăţătura.

În mai 1944 războiul era pe sfârşite, şcolile şi-au încheiat cursurile mai devreme din cauza bombardamentelor tot mai ameninţătoare; ne-am luat rămas bun de la învăţătorul nostru, Dl. Enăchescu, şi de la Şcoala primară nr. 1 din Constanţa. Ne-am continuat fiecare dintre noi drumul propriu, urmând liceul, facultatea, devenind la rândul nostru adulţi...Atunci am înţeles cu adevărat marele rol jucat de învăţătorul nostru, de la care am învăţat nu doar cititul şi scrisul, nu numai adunarea şi tabla înmulţirii, ci, mai ales, 
corectitudinea, disciplina, civilitatea în relaţiile cu oamenii şi cu lumea."

P.T. Frangopol a urmat apoi Liceul „Mircea cel Bătrân”, cel mai vechi și mai prestigios liceu de băieți din Constanța, evocând: ,anii de liceu (1944-1951) ce au avut o contribuţie majoră la promovarea unor valori fundamentale - cultura, patria, familia, credinţa, relaţiile corecte între oameni, comportarea civilizată în societate - toate acestea, la un loc şi nu numai acestea, au contribuit la dezvoltarea personalităţii mele...Intreg corpul profesoral mi-a pregătit viitorul profesional, iar calitatea profesorilor pe care i-am avut a fost esenţială... Majoritatea profesorilor aveau titlul de doctor obținut la universități germane sau franceze...Figura cea mai puternică şi mai durabilă întipărită în memorie la intrarea în clasa I de liceu, a fost prof. de română Ilarie Reit, sas originar din Râşnov,...un profesor excelent, demn urmaş al grămăticilor ardeleni. Lui îi sunt dator şi astăzi pentru modul de a scrie cât de cât corect în limba română. De la el am învăţat gramatica, de la el exprimarea corectă prin alcătuirea propoziţiilor şi frazelor, după o logică strictă... Prof. Grigore Sălceanu, de franceză, poet consacrat, era o figură calmă, olimpiană. Profesorii Rizescu şi Ioan Vodă, excelenţi pedagogi ca profesori de matematică, erau foarte prietenoşi cu noi elevii... Reforma învăţământului mi-a prilejuit mie şi colegului meu de clasă şi prieten încă de la grădiniţă, Paul Diaconescu (Puiu), şansa unui experiment interesant, realizat în clasa 3-a şi a 4-a de liceu...Nu existau manuale la toate disciplinele, mai ales la limba română şi istorie, datorită schimbărilor politice în programele şcolare...învăţam numai după notiţele expunerilor profesorilor noştri...nu puteam să ne bucurăm de o adevărată istorie a românilor, de istoria literaturii române şi universale, de spiritul umanist, de cultura literară care contribuie...încă de la începuturile adolescenţei, la formarea unui individ. Ne gândeam cum vom arăta peste câţ̧iva ani când vom termina liceul şi vom şti prea puţin din cultura şi istoria românilor şi din cea universală... Mergeam în librării şi vedeam cărţi traduse din autori care nouă nu ne spuneau nimic, iar cărţile de autori autohtoni vechi sau ai momentului ne erau necunoscute. Librarii ne lăsau să le răsfoim. Era „Biblioteca pentru toţi”, la care mă uitam cu jind, neavând bani să cumpăr. Nu aveam bibliotecă acasă, mamele casnice, taţii cu slujbe modeste care nu le permiteau cumpărarea de cărţi pentru noi şi nici bani de buzunar nu primeam...

Ne-am abonat ca cititori la Biblioteca Judeţeană Constanţa...care era la doi paşi de liceu, în Piaţa Ovidiu...Ne-am bucurat de la început de îndrumarea şefei Bibliotecii, Doamna Elena Cămară (în adevăratul sens al cuvântului, o Doamnă!) care ne înconjura cu multă dragoste şi afecţiune, de fiecare dată când intram în Bibliotecă, şi ne recomanda, discret, fără o obligativitate ca la şcoală, cu o succintă prezentare, ce cărţi să citim. Şi le parcurgeam din scoarţă în scoarţă, cum se spunea, cu mare plăcere şi nesaţ. D-na Cămară era o intelectuală şi se purta cu noi, nişte copii de fapt, cu atenţie şi politeţe, ca şi cu orice cititor matur al bibliotecii, situaţie pe care am apreciat-o din primul moment: crea o ambianţă familiară, care ne plăcea, dar ne şi flata...Sala Bibliotecii era impresionantă, pentru noi, cu rafturi suprapuse de cărţi, la care urcam ca într-un balcon, pe scări, cu mesele pentru cititori, de la parter, întotdeauna libere. Răsfoiam reviste, broşuri, scoteam din rafturi cărţi şi le răsfoiam cu nesaţ. Găseam un nou Univers...Am decis să ne apucăm să citim cărţi de literatură română şi universală, de istoria românilor şi nu numai...Ne-am luat în serios obligaţia de a citi, de a ne pune la punct cultura literară, devenind cititori permanenţi, pasionaţi, dornici de a ne completa cunoştinţele de literatură română, dar şi străină...Am fost norocoşi fiindcă...epurarea fondului bibliotecilor din toată ţara de titlurile considerate necorespunzătoare ideologic s-a realizat abia în 1948...

Am hotărât să nu mai învăţăm la şcoală decât minimul necesar ca să trecem clasa...Profesorii noştri nu ştiau ce s-a întâmplat cu noi de luam note aşa de mici. Noi ştiam: citeam lunar cca. 4-5.000 de pagini! Eu datorez cititului, literaturii, formarea mea ca om de ştiinţă, întrucât ambele sunt necesare şi complementare în dezvoltarea omului contemporan...Ne-am cumpărat un caiet de teze, care avea circa 10 pagini, şi notam titlul fiecărei cărţi, cu data începerii şi data terminării cititului, cu numărul de pagini. Nu arătam caietul prietenului şi colegului Puiu decât la sfârşitul lunii, când vedeam ce şi cât a citit celălalt. Menţionez că fiecare mergea la bibliotecă să împrumute altă carte, separat...Dar a venit anul 1948, anul reformei comuniste a învăţământului, când s-au înfiinţat liceele tehnice şi numeroase şcoli profesionale și a trebuit să dăm examenul de capacitate, de trecere în cursul superior. Ne-am mobilizat, ne-am pus, cum se spune, cu burta pe carte şi am promovat fiecare la liceul la care am dorit 
să continuăm cursul superior. Eu am dat examen (1948) să continui la liceul teoretic pe care-1 începusem, Liceul „Mircea cel Bătrân”. Liceu teoretic era unul singur pentru trei judeţe... Constanţa...Tulcea şi Călăraşi, în total...numai 40 de locuri. Competiţia a fost cruntă: peste 340 de candidaţi pe 40 de locuri! Am reuşit cu media 7,33 şi a fost o surpriză prezenţa mea printre admişi, căci în clasa IV-a aveam medii doar de trecere, 5 sau $6 \ldots$

Mai târziu am realizat beneficiile acestei hotărâri. Am căpătat o cultură umanistă, aşa cum am reuşit să ne-o însuşim, fiecare în felul lui, dar benefică în deşteptarea unei curiozităţi permanente şi, mai ales, ne-a antrenat memoria şi ne-a deschis mintea. Amintirea lecturilor literare nu mi s-a şters niciodată. În cursul superior de liceu, limba română devenise o materie familiară, iar uşurinţa cu care scriam tezele la limba română mă recomandau sigur că voi urma facultatea de litere. Menţionez că a devenit obligatoriu să mă perfecţionez în limba franceză, singur, ca să pot citi cărţi în această limbă şi texte filozofice care nu erau traduse în limba română...Am citit cu mult interes mitologia greacă, care mă fascina (doar eram de origine grecească). Neglijam acum alte discipline, matematica de exemplu, iar profesorul Ion Vodă, de matematică, dirigintele clasei, nu înţelegea ce se întâmplă cu mine. Evident, nu spuneam la nimeni. Dar eram mulţumit de îmbogăţirea culturii mele generale...Ulterior, când am recitit unele opere citite în liceu, am realizat cât de întinsă era cultura mea literară, şi nu numai a mea, ci a generaţiei mele, iar la română să ştim doar marile nume şi opere ale literaturii române...Eu datorez cititului, literaturii, formarea mea ca om de ştiinţă, întrucât ambele sunt necesare şi complementare în dezvoltarea armonioasă a omului contemporan."

P.T. Frangopol a beneficiat de reglementările vremii: în paralel cu clasa a X-a, s-a înscris la cursul de pregătire al ultimei clase de liceu, a XI-a, absolvind în același an ambele clase. Apoi s-a îndreptat către ştiinţele exacte, fiind al treilea membru din familia Frangopol care alege să lucreze în domeniul ştiinţelor chimice. Primul a fost Dumitru Frangopol (1884-1952), unchiul său, care a absolvit Politehnica din München, unde şi-a făcut şi doctoratul având ca subiect izolarea acizilor naftenici din petrolul românesc. La aniversarea centenarului industriei petroliere româneşti, este citat în editorialul Revistei de chimie (Bucureşti, nr. 10, 1957), alături de alţi iluştri pioneri ai cercetării petrolului românesc: Lazăr Edeleanu, C. Condrea, Ştefan Philipide ş.a. A fost inspector al portului Constanţa şi şef al laboratorului de chimie al portului Constanţa, pe care 1-a înfiinţat şi condus (1912-1927). A fost pe front în primul război mondial. Al doilea membru chimist al familiei a fost inginerul Ion Frangopol (văr primar cu Petre T. Frangopol) care a lucrat în industria petrolieră din Ploieşti (1930-1950).

În perioada 1951-1956 P.T. Frangopol a urmat Facultatea (Fac.) de Inginerie Chimică a Universității (Univ.) Tehnice din Iași. În 1968 avea să susțină teza „,Radicali liberi stabili din clasa diarilazotului", cu care a obținut titlul de dr. inginer la Institutul Politehnic din Timișoara, (Fac. de Chimie Organică), sub conducerea profesorului Giorgio Ostrogovich.

Acad. Victor Voicu, vicepreședinte al A.R. aprecia (în Adunarea Generală din 8 oct. 2018): „Educaţia din familie, ca și cea din școală 1-a marcat definitiv pe prof. Petre T. Frangopol...Are o carieră foarte dinamică, tumultoasă, plină de încercări şi realizări, numele lui înscriindu-se printre fondatorii unor domenii de mare interes pentru cercetarea ştiinţifică românească şi internaţională, pentru şcoala românească de chimie...A avut privilegiul de a lucra cu mari personalităţi ale ştiinţei româneşti: Acad. Horia Hulubei, Acad. C.D. Neniţescu ş.a. În ultimii 20-25 de ani s-a implicat profund în politica ştiinţei, în scientometrie, în identificarea problemelor învăţământului şi cercetării ştiinţifice româneşti. A fost redactorul şef al Revistei de politica ştiinţei şi scientometrie a Ministerului Educaţiei şi Cercetării până în 2016, când nu a mai fost finanţată...Venea cu experienţa de „reviewer" al revistei „Scientometrics", publicată de Springer...Seria de 7 volume ,Mediocritate şi excelenţă: O radiografie a ştiinţei şi învăţământului din România" este remarcabilă prin acurateţea abordării şi curajul comentariilor şi concluziilor (Petre T. Frangopol, Mediocritate şi Excelenţă - O Radiografie a Ştiinţei şi a Învăţământului din România, vol. 1, 2002, Ed. Albatros, Bucureşti; vol. 2, Casa Cărţii de Ştiinţă Cluj-Napoca, 2005; vol. 3, 2008, Casa Cărţii de Ştiinţă Cluj-Napoca; vol. 4, 2011, Casa Cărţii de Ştiinţă, Cluj-Napoca; vol. 5, 2014, Casa Cărţii de Ştiinţăa, Cluj-Napoca; vol. 6, 2016, Casa Cărţii de Ştiinţă, Cluj-Napoca; vol. 7, 2019, Casa Cărţii de Ştiinţă, Cluj-Napoca). Nu este un adulator de meserie. El vorbeşte, cu dreptate, de 
„mediocritatea ţâfnoasă”! În acelaşi spirit publică „Elite ale cercetătorilor din România: matematică, fizică, chimie" (Casa Cărţii de Ştiinţă, Cluj-Napoca, 2004). A depus un efort remarcabil să realizeze volumul „Istoria chimiei româneşti” din cadrul colecţiei „Civilizaţia românească”, închinată Centenarului Marii Uniri, coordonată de Acad. Victor Spinei, lucrare publicată la Editura Academiei Române (2018). Prof. Petre T. Frangopol a coordonat volumul, ce are 35 capitole ( 9 capitole fiind scrise de către Petre T. Frangopol), 34 autori, 444 pagini şi index de 1.100 nume.

Recent am fost alături în abordarea unei probleme de majoră actualitate şi de mare impact pentru societatea românească: Dezindustrializarea şi industrializarea României. Prin organizarea în cadrul A.R. a două workshop- uri, cu participarea unor experţi de mare autoritate, au fost analizate cele două procese în care dezindustrializarea României a generat o adevărată catastrofă atât în zona demografică cât şi a resursei umane calificate, dar şi o dependenţă de produse chimice fabricate înainte de 1990 în România, pe care în prezent le importăm din ţările vecine, care nu au rezerve de petrol şi nu şi- au distrus industria chimică, dimpotrivă, au dezvoltat-o."

Un eveniment determinant în viaţa lui P.T. Frangopol a fost întâlnirea cu savantul şi omul Horia Hulubei, creatorul IFA şi directorul său între 1956 şi 1968. După absolvirea facultăţii (1956) P.T. Frangopol s-a angajat la Institutul Petrochim din Ploiești însă, după câteva luni de zile, a fost selecționat de nou creatul Institut de Fizică Atomică (IFA) de la Măgurele să urmeze cursurile de zi, timp de un an (1956-1957), serie unică de specializare în Fizica și Tehnologia Nucleară la Facultatea de Fizică a Universitatii din București, grupa de Radiochimie „un fel de masterat al zilelor noastre, dar mai complet şi mai dur, cu două semestre universitare şi la sfârşit cu examen de absolvire, după care cei 80 de cursanţi împărţiţi în patru grupe (radiochimie, domeniu inexistent în România, electronică, biologie şi medicină precum şi alte specializări) au fost repartizaţi în diverse colective nou create în IFA." Evocarea lui Horia Hulubei de către P.T. Frangopol (în Adunarea Generală a A.R. din 8 oct. 2018) este impresionantă. „Printre marile sale calităţi erau generozitatea şi încrederea cu care se adresa celor tineri, discutând cu ei astfel aceştia să se simtă colaboratori responsabili şi nu simpli executanţi. Dintru început mi-a dat sarcina organizării de la zero a laboratorului de compuşi organici marcaţi cu Carbon-14 radioactiv, Tritiu, Deuteriu, primul de acest fel din România. Colegul Balaban, cu care primisem această însărcinare, avea ore ca asistent la catedra de chimie organică (laborator, seminarii) condusă de prof. C. D. Neniţescu şi îşi pregătea susţinerea tezei de doctorat. Mai mult, prof. Neniţescu îl ameninţase că îl va da afară dacă va lipsi de la activitatea zilnică a catedrei. Aşa încât revenea subsemnatului sarcina de a pune bazele organizării laboratorului unde trebuia să ne desfăşurăm activitatea... ...Prof. Hulubei cunoştea începuturile mele la IFA...Am fost solicitat de colectivul ciclotron, unde mi s-a dat o cameră uriaşă complet goală, fără masă, nici scaun, pe care trebuia să o transform într-un laborator de chimie. Ulterior am fost detaşat în laboratorul de chimie organică al prof. C. D. Neniţescu (1958 - 1964) de la Politehnica din Bucureşti, dar ca salariat al IFA şi cu tematică de cercetare a IFA...Noi a trebuit să învăţăm şi să ne instruim singuri prin seminarii şi lecturi individuale, să citim literatură ştiinţifică şi să ne facem o cultură de specialitate doar din literatura pe care biblioteca IFA o deţinea, fiind una din cele mai bune biblioteci ştiinţifice de institut din lume, conform unui articol apărut în SUA (Journal of Chemical Documentation, vol. 13, nr. 1, pag. 16-20, 1973, autor Francisc Kertesz, Oak Ridge National Laboratory-ORNL care a vizitat IFA, urmare invitaţiei mele de a conferenția la ORNL)...Prin această evocare vreau să subliniez că, pentru mine, la IFA totul a început de la zero...IFA a devenit un centru multidisciplinar - de excelenţă...În perioada detaşării mele la Politehnică am fost chemat de prof. Hulubei şi, cu glasul lui blând, molcom, moldovenesc mi-a spus: drăguţă, te rog să întrerupi cercetările tale la Politehnică şi să te ocupi de tehnologia preparării iodului radioactiv 131 în clădirea reactorului nuclear, care să fie apoi preluat de tehnicienii ce vor fi angajaţi special pentru producerea în serie a acestui radioizotop. Te vei întoarce apoi la Politehnică. Subliniez că NU mi-a trasat sarcina. Nu aveam laborator la dispoziţie, ci un culoar la câţiva metri sub pământ, la reactorul nuclear, unde am proiectat instalarea unei nişe speciale la atelierele IFA, care aveau maiştri mecanici excelenţi aduşi de la uzinele Malaxa. După şapte luni am reuşit să prepar acest radioizotop, pentru prima dată în România, care avea în acel moment, datorită folosirii în afecţiunile glandei tiroide, cea mai mare piaţă de desfacere dintre 
toţi radioizotopii preparaţi la reactorul nuclear de la Măgurele. Articolul publicat cu acest prilej în limba română în Revista de Chimie a fost tradus şi preluat de revista americană International Chemical Engineering 2, 357, 1962, care atestă interesul SUA prin monitorizarea activităţii de la Măgurele...

Rezultatele mele ştiinţifice...citate în literatură şi în cărţi de specialitate...mi-au adus invitarea la conferinţe internaţionale reputate, cu participare limitată, de ex. Gordon Conferences, Conference Euchem etc., dar şi stagii postdoctorale în Canada şi SUA şi o bursă Dozentenstipendium Humboldt (1972)...Deşi am primit numeroase oferte de a rămâne în străinătate, m-am reîntors la IFA unde eram şef al unui laborator important cu o dotare la standarde internaţionale, căruia îi stabilisem un profil şi unde dezvoltasem primele tehnologii de preparare şi tehnici de măsurare a compuşilor organice marcaţi cu izotopi radioactivi. Din nefericire, la cutremurul din 1977 laboratorul meu a fost distrus in totalitate de un incendiu...

A început a doua etapă a activităţii mele la IFA, 1977 - 1990, devenit IFIN, când din nou am luat totul de la zero. A trebuit să-mi găsesc spaţiu şi să-mi dotez noul laborator. În plus, cercetarea ştiinţifică, în special cea de chimie de la IFA, a fost obligată să se autofinanţeze $100 \%$, neavând alocări de la buget ca până atunci, urmare a indicaţiilor venite de la partid. Această nouă situaţie a însemnat realizarea unei producţii de produse marcate radioactiv, vandabile, iar rezultatele cercetării trebuiau să aibă aplicaţii directe în industrie. În această a doua etapă am contribuit la realizarea unui obiectiv important, Centrul de Producţie Radiochimică (CPR), de la faza iniţială (proiect, documentare, dezvoltare de noi tehnologii de radiofarmaceutice şi radioizotopi)...În plus, am dezvoltat şi proiecte noi de cercetare aplicativă cu impact naţional şi internaţional, folosind...rezonanţa electronică de spin (RES), rezonanţa magnetică nucleară (RMN), spectrometria de masă, precum şi tehnologiile de preparare a unor compuşi marcaţi radioactiv prin dezvoltarea a două direcţii noi de cercetare, inexistente la IFIN: chimia biofizică şi biofizica, în care am angrenat colective de chimişti, fizicieni, medici şi biologi, atât din institut cât şi din Bucureşti şi din provincie, în cadrul unui program de cercetare al medicamentului original românesc, care s-a desfăşurat timp de 10 ani, fiind finanţat de Ministerul Industriei Chimice prin Centrala Industrială de medicamente. S-a asigurat astfel - constant - plata salariilor."

În aceeași Adunare Generală din 8 oct. 2018 am expus și eu motivele pentru care Prof. Frangopol reprezintă un model de om de ştiinţă din categoria Excelenţei, care s-a impus în România şi pe plan internaţional în chimie, radiochimie, biochimie, biofizică şi politica ştiinţei şi de aceea îl consider o Excelenţă a Excelenţei.

Prof. Frangopol a jucat un rol de seamă în viaţa mea. Îmi amintesc de prima discuţie pe care am avuto în 1977, într-un laborator al Disciplinei de Biochimie a Institutului de Medicină şi Farmacie - IMF Cluj-Napoca (devenit ulterior Universitatea de Medicină şi Farmacie - UMF - „Iuliu Haţieganu” din Cluj-Napoca), eu fiind pe atunci asistent universitar la disciplină. Eram absolvent al Facultatii de Medicină a IMF şi al Facultatii de Chimie a Universităţii „Babeş-Bolyai” (UBB) din Cluj-Napoca. Tocmai mă înapoiasem după 12 luni de specializare în Anglia (post-doc în laboratorul prof. Dennis Chapman), unde învăţasem aplicarea în studiul biomembranelor a unor tehnici moderne biofizice de biologie moleculară, între care marcarea cu spin („spin labelling”) şi rezonanţa magnetică nucleară (RMN). Mentorii mei, prof. Ioan Manta (care mi-a fost şi conducător de doctorat) şi prof. Octavian Bârzu (ce preluase conducerea disciplinei după pensionarea prof. Manta) mi-au încredinţat conducerea unui colectiv de cercetare (primul ,grup Benga”), din care făceau parte cadre didactice şi studenţi.

Prof. Frangopol mi-a oferit şansa de a începe o colaborare ştiinţifică. Domnia sa era cu 11 ani ,mai mare" decât mine, fiind un cercetător cu o formare mai completă şi cu o experienţă de cercetare mai mare. Am fost onorat că un cercetător cu o, ,carte de vizită” impresionantă (prin realizări concrete, nu doar prin „titluri”) îmi propune să colaborăm, mai ales că temele propuse valorificau specializarea mea ca post-doc şi se încadrau în programele de cercetare ce mi le propusesem. Prof. Frangopol m-a invitat să-i vizitez laboratorul la Institutul de Fizică şi Inginerie Nucleară (IFIN) Măgurele - Bucureşti, unde am avut onoarea de a o cunoaşte pe distinsa soţie dr. Maria Frangopol, excelent cercetător şi OM deosebit. Cei doi soţi lucrau împreună, fiind conducătorii ,grupului prof. P.T. Frangopol şi dr. Maria Frangopol", în care mai lucrau şi tineri cercetători, cărora prof. Frangopol le finanţa posturile obţinute 
prin contractele sale. A început astfel o colaborare de câteva decenii între ,grupul prof. P. T. Frangopol şi dr. Maria Frangopol” de la IFIN Măgurele - Bucureşti şi „,grupul Benga” de la IMF Cluj-Napoca, grup ce s-a dezvoltat foarte mult după înfiinţarea (1978) Disciplinei de Biologie Celulară, a cărei conducere mi s-a încredințat.

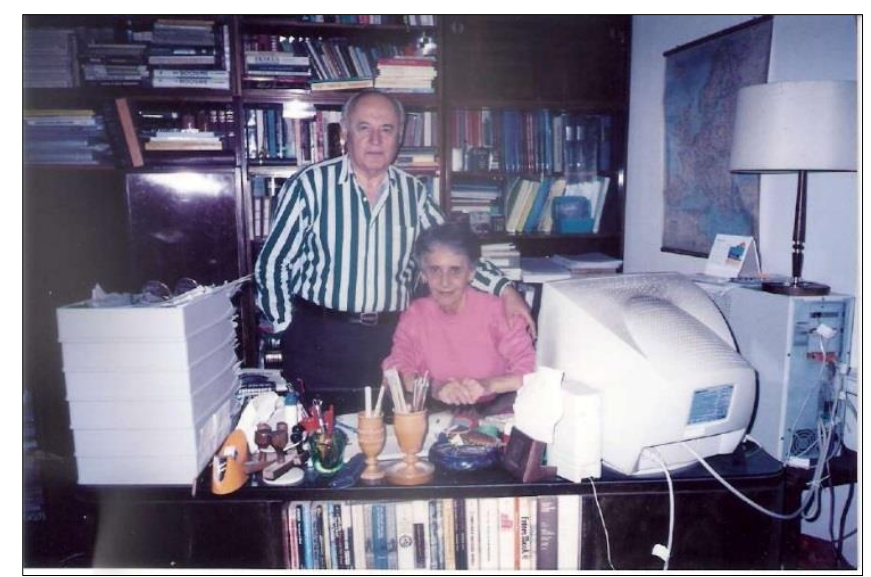

Petre Frangopol și Maria Frangopol în 2004 la biroul de lucru

Voi reda unele rezultate valoroase ale colaborării dintre cele două grupuri. Formarea unor tineri cercetători cărora noi le-am creat posturi şi condiţii de muncă, i-am învăţat „,cum se face ştiinţa”, este unul dintre cele mai de seamă rezultate. Dar să redau şi unele programe de colaborare şi rezultatele ştiinţifice obţinute, valorificate prin publicarea lor în jurnale importante din România şi din străinătate. Prima temă de colaborare a celor două grupuri a urmărit caracterizarea, prin rezonanța electronică de spin (RES) cu markeri specifici, a interacţiunilor moleculare dintre proteine-lipide, lipide-lipide, în sisteme model şi pe membrane naturale, precum şi a efectelor unor medicamente. Pentru mine a fost o continuare a cercetărilor începute în Anglia în lab. prof. Dennis Chapman, însă lab. soţilor Frangopol de la IFIN era unul dintre puţinele laboratoare din lume în care se sintetizau markeri de spin, iar unii s-au obţinut prin colaborarea dânşilor cu grupul prof. Rozantsev din Moscova. Soţii Frangopol au adus în colaborare markerii de spin şi expertiza „,chimică”, iar eu am adus expertiza de preparare a probelor biologice: proteine, membrane artificiale sau modele de membrane (vezicule numite liposomi), membrane eritrocitare, membrane subcelulare hepatice - microsomi (vezicule derivate din reticulul endoplasmic), de marcare cu spin, de efectuare a măsurătorilor la spectrometrul RES şi de interpretare a spectrelor. Amintesc lucrările: V.D. Sholle, E.Sh. Kagan, V.J. Michailov, E.G. Rozantsev, P.T. Frangopol, Maria Frangopol, V.I. Pop, Gh. Benga, Rev. Roum. Biochim., 17, 291-298, 1980; P.T. Frangopol, Gh. Benga, M.S. Ionescu, Maria Frangopol, O. Popescu, V.I. Pop, Bul. Acad. Şt. Med., nr. 1, 39-49,1982; Gh. Benga, V.I. Pop, M. Ionescu, Adriana Hodârnău, Rozalia Tilinca, P.T. Frangopol, Biochim. Biophys. Acta, 750, 194-199, 1983; Gh. Benga, I.C. Dânşoreanu, Maria Frangopol, P. T. Frangopol, Rev. Chim. 59, 1255-1259, 2008. Subliniez că prof. Frangopol m-a învăţat cum se scriu proiecte de contracte de cercetare ştiinţifică spre a fi aprobate şi finanţate, dânsul având o experienţă deosebită pentru obţinerea de fonduri din ţară şi din străinătate. A fost pentru mine un adevărat profesor pe această linie, la fel şi pentru regretatul şi talentatul om de ştiinţă care a fost biofizicianul dr. Vasile V. Morariu (ITIM Cluj-Napoca).

Printr-un contract de cercetare cu Academia de Ştiinţe Medicale (ASM) eu am obţinut dotarea Disciplinei de Biologie Celulară a IMF Cluj-Napoca cu spectrometrul RES ART-6 produs la IFIN. Am elaborat împreună cu ,grupul Frangopol” şi două ample publicaţii sub forma de reprint, tipărite la Institutul Central de Fizică (ICEFIZ) al IFIN, privind marcarea cu spin şi folosirea spectrometrului RES ART-6: P.T. Frangopol, Maria Frangopol, M.S. Ionescu, V.I. Pop, Gh. Benga, Markeri de spin. Aplicaţii in biologie, Reprint ICEFIZ RB-3, noiembrie 1980; M.S. Ionescu, V. Strujan, Maria Frangopol, M. Ciobanu, V.D. Sholle, Gh. Benga, P.T. Frangopol, Folosirea spectrometrului RES ART-6 IFIN în studii 
cu markeri de spin, Reprint ICEFIZ RB-4, iunie 1981. Astfel s-a contribuit la informarea teoretică şi practică a tuturor cercetătorilor din România interesaţi de utilizarea unei tehnici moderne de biofizică, biochimie şi biologie moleculară. De menţionat că între autorii lucrărilor publicate ca valorificare a colaborării dintre „grupul Frangopol”, pe de o parte şi „grupul Benga”, pe de altă parte, au fost incluşi tineri din ambele grupuri. Exemple de asemenea lucrări sunt: Gh. Benga, M. Ionescu, O. Popescu, V. I. Pop, Mol. Pharmacol., 23, 771-778, 1983; Gh. Benga, O. Popescu, R.P. Holmes, V.I. Pop, Bull. Magnetic Resonance, 5, 265, 1983; Gh. Benga, V.I. Pop, O. Popescu, M. Ionescu, V. Mihele, J. Membrane Biol., 76, 129-137, 1983. O lucrare importantă realizată împreună cu prof. Frangopol este următoarea: Gh. Benga, Adriana Hodârnău, M. Ionescu, V.I. Pop, P.T. Frangopol, V. Strujan, R.P. Holmes, F.A. Kummerow, Ann. New York Acad. Sci., 414, 140-152, 1983, publicată în volumul „Biomembranes and Cell Function” (F.A. Kummerow, Gh. Benga, R.P. Holmes, eds.), cuprinzând lucrările prezentate la un workshop româno-american organizat de F.A. Kummerow şi Gh. Benga (New York, 1982).

Prof. Frangopol a dat un sprijin important şi programului de colaborare început în 1976 între ,grupul Benga” de la IMF Cluj şi ,grupul Vasile V. Morariu” de la ITIM Cluj-Napoca privind studiul prin RMN al transportului apei prin membrana celulei roşii, program prin care s-a standardizat metodologia de RMN pentru măsurarea difuziunii (transportului) apei prin membrana eritrocitară: V.V. Morariu, Gh. Benga, Biochim. Biophys. Acta, 469, 301- 310, 1977. Benga şi Morariu au efectuat și determinări de permeabilitate a hematiilor de la copii cu diferite forme clinice de epilepsie, comparativ cu copiii dintrun lot martor. S-a observat o permeabilitate scăzută pentru apă a hematiilor de la copiii cu epilepsie, propunându-se ideea originală a existenţei unui defect de membrană cu caracter generalizat în epilepsie. S-a publicat lucrarea: Gh. Benga, V. V. Morariu, Membrane defect affecting water permeability in human epilepsy, Nature, 265, 636-638, 1977. Datele clinice au fost prelucrate de dr. Ileana Benga (soţia dr. Gh. Benga) care lucra în Clinica de Neuropsihiatrie infantilă a I.M.F. Cluj-Napoca, iar din întâmplare şi Cornelia Morariu (soţia lui Vasile Morariu) era intern în clinica respectivă. Ileana Benga şi Cornelia Morariu meritau să fie incluse între autori. Această lucrare a fost punctul de pornire a programului meu de cercetare vizând identificarea proteinei implicată în transportul apei prin membrana eritrocitară. Pentru acesta era necesară amenajarea laboratorului de lucru cu radioizotopi. Eu şi Octavian Popescu (în prezent academician) aveam dreptul de a lucra cu radioizotopi pe baza studiilor universitare (Octavian absolvise Fac. de ştiinţe, secţia de biologie moleculară la Univ. din Belgrad, iar eu absolvisem la UBB anul V de specializare în chimia suprafeţelor şi radiochimie). Un alt membru de bază al „grupului Benga” ce urma să facă experienţa, Ioan Victor Pop, a fost înscris la Cursul de utilizare a radioizotopilor de la IFIN Bucureşti-Măgurele (sprijinul prof. Frangopol fiind esenţial), unde a luat ca proiect de licenţă amenajarea laboratorului de radioizotopi al Disciplinei de Biologie Celulară. După cum este descris în alte prezentări (Gh. Benga, Cell Biol. Int. 27, 701-709, 2003; Gh. Benga, Mol. Asp. Med., 33, 518-534, 2012) ,grupul Benga” a descoperit în 1985 prima proteină canal pentru apă din membranele biologice (proteină numită în prezent aquaporina1). Descoperirea s-a raportat în 1986 în două lucrări de referinţă (,milestones papers”): Gh. Benga, O. Popescu, V.I. Pop, R.P. Holmes, Biochemistry, 25, 1535-1538, 1986; Gh. Benga, O. Popescu, Victoria Borza, Ana Mureşan, V.I. Pop, I. Mocsy, A. Brain, J. Wrigglesworth, Eur. J. Cell Biol., 41, 252-262, 1986. Din păcate Premiul Nobel pentru chimie pe 2003 a fost acordat pentru această descoperire unui savant american, care a redescoperit aceeaşi proteină din întâmplare, publicând prima lucrare la 2 ani după lucrările publicate de ,grupul Benga”.

Prof. P.T. Frangopol a fost primul pe care 1-am contactat (la telefon) când a fost anunţată nominalizarea laureatului. Reacţia prof. Frangopol a fost promptă: „E un nou caz Paulescu, trebuie să reacţionăm!" M-a sprijinit în acţiunea pe care am început-o atunci, de recunoaştere a priorităţii mele în descoperirea primei proteine canal pentru apă, prin strângerea de semnături de sprijin a „PETIȚIEI pentru recunoaşterea lui Gheorghe Benga ca un descoperitor al primei proteine canal pentru apă în membrana celulei roşii sanguine umane, cu câţiva ani înaintea lui Peter Agre (Premiul Nobel pentru Chimie în 2003)." Sprijinul Prof. Frangopol, ca și cel al multor membri marcanți ai Academiei Române (acad. Mihai Drăgănescu, președinte al Secţiei de Ştiinţa şi Tehnologia Informaţiei; acad. Victor Voicu, 
președinte al Secţiei de Ştiinţe Medicale; acad. Ionel Haiduc, pe atunci preşedinte al Filialei Academiei Române din Cluj-Napoca; acad. Ioan Dumitrache, pe atunci preşedinte al CNST) este descris în articolul publicat on-line în decembrie 2021: Gh. Benga, Remembrance of Petre T. Frangopol (1933-2020) the promoter of scientometrics in Romania, Scientometrics, https://doi.org/10.1007/s11192-021-04213-5.

În sprijinul petiţiei au semnat mii de oameni de ştiinţă din întreaga lume, între care Laureatul Nobel, George Emil Palade, precum şi marea majoritate a membrilor Academiei Române. Îi sunt recunoscător prof. Petre T. Frangopol pentru promovarea descoperirii româneşti a primei proteine canal pentru apă din membranele biologice în mai multe publicaţii: P. T. Frangopol, L. Gavrilă, Memorandum regarding the discovery of the first water channel protein by Gheorghe Benga in Romania, a few years before Peter Agre, 2003 Nobel Prize in Chemistry, Romanian J. of Genetics, 1, 2005); P.T. Frangopol, Mediocritate şi excelenţă. O radiografie a ştiinţei şi învăţământului din România, Vol. 2, Fundaţie OutNobel la ClujNapoca, p.257-26, Casa Cărţii de Ştiinţă, Cluj-Napoca, 2005; P. T. Frangopol, Mediocritate şi excelenţă. O radiografie a ştiinţei şi învăţământului din România, Vol. 3, Cap. 14. Gheorghe Benga, exclus de la Premiul Nobel 2003 pentru chimie, fondatorul Biologiei Celulare şi Moleculare la ClujNapoca, Casa Cărţii de Ştiinţă, Cluj-Napoca, 2008; P. T. Frangopol, Gheorghe Benga exclus de la Premiul Nobel 2003 pentru chimie, fondatorul Biologiei Celulare şi Moleculare la Cluj-Napoca, Revista de Politica Ştiinţei şi Scientometrie - serie nouă -, 2, 48-62, 2013. De asemenea P.T. Frangopol a fost Invited Speaker, susţinând Opening Lecture la: „The Second World Congress on Water Channel Proteins (Aquaporins and Relatives) Celebrating the 30th Anniversary of the Discovery of the First Water Channel Protein (Later Called Aquaporin 1), 6-10 May 2015, Cluj-Napoca, Romania".

Prof. Frangopol a jucat un rol important şi în primirea mea în Academia Română. Dosarul meu de candidat (depus în 1990) a fost ,,pus bine" în dulapul din spatele biroului acad. Nicolae Cajal (vicepreşedinte al A.R. şi preşedinte al Secţiei de Ştiinţe Medicale), până ce prof. Frangopol i 1-a semnalat. Astfel am devenit m.c. al Academiei în 2001 (după 11 ani), iar m.t. în 2015 (deci după încă 14 ani).

În 1990 P.T. Frangopol a fost invitat profesor universitar la Universitatea „Al. I. Cuza” din Iaşi (UAIC), spre a înfiinţa o secţie de biofizică la Facultatea de Fizică pe baza experienţei sale de la IFA. Rectorul Gh. Popa şi decanul Mircea Sanduloviciu 1-au avertizat că nu-i pot oferi nimic şi s-au ţinut de cuvânt $100 \%$. P. T. Frangopol a acceptat, conştient că pleca din nou de la zero în cariera sa, într-o nouă activitate care pur şi simplu îl provoca. A imaginat soluţii care să-i permită o finanţare. Avea experienţa contractelor prin care supravieţuise de ani buni la Măgurele. A reuşit înfiinţarea unei secţii de fizică medicală, prima secţie nou înfiinţată într-o Univ. din România, de asemenea, un laborator de biofizică (al doilea din ţară după Universitatea din Bucureşti), amenajat într-un spaţiu din subsolul universităţii, totalmente impropriu. A reuşit ca în aceste condiţii secţia de fizică medicală să devină cea mai râvnită secţie a Facultatii de Fizică. Pentru ca studenţii să aibă literatură ştiinţifică de biofizică pentru tezele de licenţă la nivelul progreselor ştiinţifice internaţionale a iniţiat şi coordonat o serie de volume, Current topics in Biophysics, apărute la Editura UAIC, volume cu autori din 35 mari laboratoare ale lumii, cu o difuzare internaţională. Tezele de licenţă ale studenţilor săi erau realizate peste hotare, în laboratoarele cu care avea colaborări ştiinţifice în diferite ţări europene şi care aveau dotări corespunzătoare. Absolvenţii secţiei, pe care i-a sprijinit necondiţionat în dezvoltarea lor profesională prin recomandarea lor marilor universităţi din străinătate pentru susţinerea doctoratelor, au fost reţinuţi ulterior de diferite universităţi, ajungând profesori la universităţi din Germania (Free Univ. of Berlin), Suedia (Umea Univ. şi Linköping Univ.), SUA (Univ. of California at Irvine, Stanford Univ.,Texas A\&M Univ.), Australia (Univ. of Queensland), Irlanda (Univ. College Dublin), Grecia (Univ. din Atena), Austria (Univ.din Graz) etc.

P.T. Frangopol și-a continuat cariera de prof. la Facultatea de Medicină a Universitatii de Vest „Vasile Goldiș” din Arad (1997-1999, predând biofizică și fizică medicală), la Facultatea de Chimie a Universitatii "Babeș-Bolyai" din Cluj-Napoca - (1999-2002, unde a dotat secţia de chimie fizică cu aparatură în valoare de cca. 200.000 USD dintr-un grant al Băncii Mondiale) și la Departamentul de fizică al Universitatii Politehnica din București (2002-2004). La toate universitățile a fost foarte apreciat 
de către studenți și cadrele didactice pentru competența profesională și pentru calităţile umane unice.

În ceea ce priveşte activitatea sa publicistică, fiind un martor dỉn interior al dezvoltării cercetării româneşti (din 1956 până în 2020), a considerat în permanenţă ca o datorie morală să-şi exprime opinia asupra rezultatelor cercetării româneşti. A sugerat profesorului Hulubei în 1961, înfiinţarea Buletinului de informare al IFA, al cărui coordonator a fost, buletin care constituie şi astăzi o sursă valoroasă de informare despre activitatea IFA. În 2012 a devenit redactorul şef al Revistei de Politica Ştiinţei şi Scientometriei, revistă a Ministerului Educaţiei şi Cercetării, pe care a coordonat-o până în 2016, când ministerul a tăiat finanţarea revistei. În paralel a publicat zeci de articole pe tema cercetării şi educaţiei în şcoala românească în suplimentul Aldine al ziarului România Liberă, în Contemporanul, Tomisul Cultural, Tribuna Școlii, Steaua, Forum, Știință și Tehnică, Curierul de Fizică.

Acad. Ioan Dumitrache, Secretar General al A.R. spunea în Adunarea Generală din 8 oct. 2018: „Prin acţiunile şi demersurile sale distinsul coleg Petre Frangopol şi-a adus contribuţia la înfiinţarea, pentru prima dată în România, a unui centru pentru politica ştiinţei şi scientometrie în cadrul Consiliului Naţional pentru Cercetare Ştiinţifică din Învăţământul Superior. Acest centru (CENAPOSS) a reunit preocupările tuturor structurilor interesate în promovarea ştiinţei româneşti şi creşterea vizibilităţii acesteia pe plan internaţional... Au fost identificate şi evaluate centre de cercetare din universităţi, a fost lansat programul de susţinere a literaturii ştiinţifice relevante prin evaluarea revistelor şi editurilor de carte ştiinţifică."

$\mathrm{Cu}$ același prilej Profesorul Dorin Poenaru (m.o. al Academiei Române) a subliniat că activitatea ştiinţifică a Prof. P.T. Frangopol se caracterizează printr-o arie largă de cuprindere şi un grad neobişnuit de interdisciplinaritate, preocupările sale cuprinzând chimia, radiochimia, biologia, biochimia, biofizica, fizica, ştiinţele inginereşti, arheometria. P.T. Frango pol a fost cel care a dezvoltat pentru prima dată în ţară producţia radiofarmaceuticelor cu radioizotopi produşi la ciclotronul IFA (Galiu-67, Indiu-111), cei mai folosiţi în diagnosticul cancerului. A pus la punct, pentru prima dată la noi, tehnicile de lucru privind sinteza compuşilor marcaţi cu C-14, măsurarea radioactivităţii lor şi urmărirea mecanismelor de reacţie cu ajutorul compuşilor marcaţi izotopic care au făcut obiectul a numeroase lucrări. S-a ocupat şi de marcări cu Deuteriu (D), de exemplu, a preparat pentru prima dată tetradeutero-N-hidroxi-succinimida (J. Amer. Chem. Soc., 93, 6561, 1972), precum şi o serie de săruri de piridiniu care prezintă o activitate fiziologică marcată (J. Organic Chem., 38, 2355 (1973). A dezvoltat un domeniu nou, premieră pentru radiobiologia românească, metoda C-14 pentru determinarea productivităţii primare a planctonului în ecosistemele acvatice româneşti cu rezultate originale publicate în literatura de specialitate (Oceanologica Acta, 4, 343, 1981; Marine Ecology, $19,25,1984)$.

Printre domeniile în care Petre Frangopol a avut preocupări se numără deci: chimia organică, chimia fizică organică, radiochimia, chimia biofizică, biofizica, fizica medicală, arheometria, oceanografia, politicile științei și managementul în acest domeniu, scientometria, istoria chimiei în România. Este autor a peste 330 de lucrări științifice publicate în periodice românești și străine de specialitate, peste 150 fiind menționate de Science Finder - publicație a Societății de Chimie din SUA. A fost și membru în colegiile editoriale ale revistelor Journal of Radioanalytical and Nuclear Chemistry, Scientometrics și Romanian Journal of Chemistry. Din 1969 a fost, peste 20 de ani, unul din cei doi abstractori români la Chemical Abstracts Service (CAS), Columbus, Ohio, SUA, contribuind (decisiv) la includerea Revistei de Chimie printre revistele indexate și abstractate de CAS. La CNCSIS a contribuit (decisiv) la aducerea pentru prima dată în țară a băncii de date Science Citation Index publicată de Institute of Scientific Information din Philadelphia - SUA. A contribuit la IFA la dezvoltarea Bibliotecii, care a devenit cea mai bogată și completă bibliotecă de chimie din țară și una dintre cele mai bune biblioteci interdisciplinare de institut din lume, la un moment dat având 2500 de abonamente.

Acad. Victor Zamfir spunea în Adunarea Generală din 8 oct. 2018: „Prof. Frangopol face parte din prima generaţie de cercetători care s-au dezvoltat împreună cu IFA şi care prin rezultatele sale s-a impus nu numai ca un creator la nivelul ştiinţei internaţionale, dar şi ca un ctitor de domenii noi în ştiinţa românească la nivelul celor din lume." Acad. Nicolae-Victor Zamfir a menționat că Prof. Frangopol a organizat și numeroase manifestări culturale, ce aveau legătură cu IFA, ce s-au bucurat de mare succes. 
Sediul actual al IFA (IFIN) de la Măgurele se află pe domeniul de altădată al moşiei şi conacului Oteteleşeanu de la Măgurele, iar acolo a funcţionat la sfârşitul sec. XIX şi începutul sec. XX Institutul de fete „Oteteleşeanu” al cărui director a fost între 1894 - 1908 Ioan Slavici. Prin strădaniile prof. Frangopol a avut loc la Măgurele în octombrie 2008 o manifestare (prezentată de România literară nr. 51-52 din decembrie 2008) închinată lui Ioan Slavici, de la a cărui naştere s-au împlinit 160 de ani. Prof. Frangopol a organizat ( 15 iunie 2015) și o masă rotundă la Mănăstirea Bârsana din Maramureș privind „Colaborarea ştiinţifică Horia Hulubei - Yvette Cauchois şi spiritualitatea maramureşeană" (comunicările fiind publicate, Casa Cărții de Știință, 2016). Yvette Cauchois, colaboratoarea profesorului Hulubei în Franţa (1930 1938), a dorit, prin testament, să fie înmormântată la Mănăstirea Bârsana.

P.T. Frangopol a fost un susţinător neobosit al recunoaşterii valorilor autentice ale învăţământului şi cercetării din România. În anul 2004 a publicat volumul Elite ale Cercetătorilor din România (Casa Cărţii de Ştiinţă, Cluj-Napoca, 2004) în care prezintă biografiile a 21 de cercetători de elită din domeniul matematicii, fizicii şi chimiei. Aprecierea s-a adeverit a fi corectă prin faptul că 7 dintre aceştia au devenit ulterior membri ai A. R.: Voicu Lupei, Dumitru Mihalache, Dorel Bucurescu, Mihnea Colţoiu, Dorin N. Poenaru, Nicolae-Victor Zamfir şi Geavit Musa. P. T. Frangopol a fost un promotor al scientometriei în România, publicând mai multe lucrări, între care: P.T. Frangopol, Indicele Hirsch - un nou indicator scientomeric, Academica, XVI, 70-72, 2005.

Profesorul Livius Trache a expus în Adunarea Generală din 8 oct. 2018 implicarea Prof. P.T. Frangopol în activitățile din IFIN legate de patrimoniul cultural național, care s-au desfãșurat pe un interval de 3 decade. La început au fost simple iniţiative personale privind aspecte de numismatică (determinarea concentraţiilor elementelor majore: aur, argint, cupru în tezaure). Apoi s-a dezvoltat şi atestat importanţa domeniului arheometriei în România. Prof. P.T. Frangopol s-a implicat în organizarea unor serii de conferinţe şi seminarii naţionale sau locale ale istoricilor, cu prezentări ale rezultatelor diferitelor colective, din ce în ce mai numeroase. Primele două conferinţe naţionale au avut loc în 1987 şi 1989, la Cluj-Napoca. Între 1990-2007 au avut loc cca. 20 simpozioane de arheometrie, toate organizate în provincie. Primele publicaţii în domeniu au fost tipărite la editura ICEFIZ (Institutul Central de Fizică) din Bucureşti, ambele în limba engleză, care au fost difuzate internaţional în sute de exemplare şi ale căror lucrări au fost citate în literatura de specialitate: P.T. Frangopol and V.V. Morariu (eds.), First Romanian Conference on the application of Physics Methods in Archaeology, Cluj-Napoca, 5-6 November 1987, ICEFIZ, Bucharest, Romania, vol. 1, 1988; P.T. Frangopol and V.V. Morariu (eds.), Archaeometry in Romania, $2^{\text {nd }}$ Romanian Conference on the application of Physics Methods in Archaeology, Cluj-Napoca, 17-18 February 1989, ICEFIZ, Bucharest, Romania, vol. 2, 1990. P.T. Frangopol și V.V. Morariu au organizat (pentru prima dată în România) The $8^{\text {th }}$ workshop Balcanic Days of Biochemistry and Biophysics, Cluj- Napoca, 1990.

P.T. Frangopol a fost onorat prin publicarea de numere speciale din reviste dedicate personalității sale: Revista de Chimie (vol. 59, nr. 11, 2008, cu prilejul aniversării sale la 75 de ani), STUDIA UBB CHEMIA (vol. LXVI, nr. 3, 2021), precum și prin articole In Memoriam publicate în alte reviste. Activitatea sa a fost recunoscută prin alegerea sa în comitetele de redacţie ale revistelor Revue Roumaine de Chimie (Romanian Journal of Chemistry), Journal of Radioanalytical and Nuclear Chemistry și Scientometrics (ambele editate de Springer, Germania).

Activitatea i-a fost apreciată şi prin acordarea unor distincții: Diploma de Onoare şi Medalia IFA (2010), Profesor de onoare al UMF „Iuliu Haţieganu” Cluj-Napoca (2008), Diploma de Onoare „Horia Hulubei” a IFIN-HH (2006) pentru activitatea depusă în IFA şi la IFIN-HH, Diploma de Excelenţă a Univ. Bucureşti (2018), Marea Diplomă de Onoare, decernată în 1997 de Comisia Naţională de Arheometrie, Muzeul Naţional de Istorie a Transilvaniei, Diploma de Onoare a Institutului de Cercetări Marine din Constanţa, Premiul „C. Miculescu” al Academiei Române (1986) pentru rezultatele obţinute în programul de Chimie Biofizică şi Biofizică la IFA, Medalia „,Madona României”" decernată de către Monseniorul Dr. Ioan Robu, Arhiepiscop-Mitropolit, cu prilejul aniversării Centenarului înfiinţării Arhiepiscopiei Romano- Catolice de Bucureşti şi împlinirii a două milenii de creştinism în România. Cred că primirea ca m.o. al Academiei Române (24 oct. 2012), omagierea sa în 
8 oct. 2018 în Aula A.R. la împlinirea vârstei de 85 de ani, precum şi acordarea titlului de cetăţean de onoare într-o spendidă ceremonie organizată de către autorităţile din urbea natală (8 iulie 2019) au fost recunoașterile care i-au produs cele mai mari satisfacții.

Prof. Petre T. Frangopol a lucrat în IFA până în 1993. După pensionare a pus la dispoziția societății experiența acumulată, ocupând diverse posturi de consilier. În perioada 1995-1998 a fost consilier al vicepreședintelui Academiei Române, iar în perioada 2002-2010 a fost consilier științific la CNCS. De asemenea, a fost consilier la IFIN-HH și membru în Comisia prezidențială pentru analiza și elaborarea de politici în domeniul educației și cercetării.

Caracterul nobil al Prof. Petre T. Frangopol este dovedit și prin recunoașterea rolului esențial pe care 1-a jucat în viața sa Dr. Mioara Frangopol, distinsa lui soție. În Adunarea Generală a A.R. din 8 oct. 2018 dedicată celei de a 85-a aniversări a sale P. T. Frangopol a spus în final: „Întreaga mea viaţă, întreaga mea activitate ştiinţifică este legată de soţia mea, Mioara, care mi-a stat alături, umăr la umăr, timp de 58 de ani până a trecut în eternitate. Cuvintele nu pot exprima cât de mult îi datorez: afecţiunea cu care m-a înconjurat, prietenia şi colaborarea ei dezinteresată, sprijinul său necondiţionat m-au ajutat să finalizez tot ce am realizat şi să devin ceea ce sunt azi, acum, în faţa Dvs. Ea a fost totodată pentru mine şi un preţios colaborator şi consilier. Mulţumită sfaturilor sale n-am răspuns invidiilor, răutăţilor şi calomniilor cu care am fost confruntat în viaţa cea de toate zilele. Devotamentul cu care m-a înconjurat şi caracterul ei, m-au ajutat şi încurajat să desfăşor activităţile pe care le începeam mereu de la zero, aşa cum am pomenit mai înainte, activităţi în care, datorită în primul rând ei, nu mă simțeam singur. Mioara, cu o minte sclipitoare şi cu o pregătire profesională de excepţie, şi-a pus întreaga existenţă în slujba carierei mele şi a armoniei în căsnicia noastră, drept pentru care îi port o recunoştinţă veşnică."

Petre T. FRANGOPOL rămâne o personalitate unică în istoria chimiei şi culturii române, iar pentru cei ce 1-au cunoscut personal, Petrache rămâne un prieten de neuitat.

\section{Acad. GHEORGHE BENGA}

Romanian Academy, Academy of Medical Sciences of Romania School of Molecular Biosciences, University of Sydney, Australia 